Research Article

\title{
Working Capital Management and Its Impact on Firms' Performance: An Empirical Analysis on Ethiopian Exporters
}

\author{
Fekadu Agmas Wassie \\ Department of Accounting and Finance, College of Business and Economics, Debark University, Debark, Ethiopia \\ Correspondence should be addressed to Fekadu Agmas Wassie; fekaduagmas2005@gmail.com
}

Received 25 November 2020; Revised 22 February 2021; Accepted 13 March 2021; Published 20 March 2021

Academic Editor: Yu-Min Wang

Copyright (C) 2021 Fekadu Agmas Wassie. This is an open access article distributed under the Creative Commons Attribution License, which permits unrestricted use, distribution, and reproduction in any medium, provided the original work is properly cited.

\begin{abstract}
Companies may have their level of optimal working capital that maximizes their values through the effective management of current liabilities and assets. Previously, many studies were made on the impact of working capital management on the company's performance in different sectors; however, its impact on the performance of firms that are engaged in export activities was not given any consideration and this particular study has attempted to investigate the fundamental impact of working capital management on the export firm's performance in Ethiopia. To analyze this particular study, a total of 164 exporters operating in Ethiopia have been taken as a sample and both primary and secondary data collection methods were used. The data gathered from the sample of the study were analyzed using a multiple linear regression model and the result reveals that working capital management which was measured by account receivables period, cash conversion cycle, and accounts payable period has a statistically significant and positive correlation with the performance of exporting firms in Ethiopia which was measured by both return on assets and return on investment. However, working capital management which was measured by the inventory conversion period has a statistically significant and positive impact on return on investment, but it has an insignificant impact on the performance of sampled export firms in Ethiopia which was measured by return on assets. Based on the result of the study, firms may need to extend credit terms for customers, may prolong their cash conversion cycle, may need an extended payment period, and may or may not hold a high volume of inventory. All extending periods and cycles shall be made up to the extent of attaining an optimal level of working capital and better to implement a conservative policy of working capital management. Thus, it is advisable to consider the result of this study while making decisions regarding their working capital management to support their performance.
\end{abstract}

\section{Background of the Study}

Today's financial management, specifically the management of and control of working capital, needs huge attention and it is a difficult task due to the existence of a high portion of working capital in a business. The administration of current assets which has an accounting year to convert into cash and current liabilities which is payable within a year and the relationship among the two may be considered as working capital management [1].

As it is known, both the current assets and current liabilities are presented in a given business. The current assets and current liabilities are vital for the operation of different businesses. However, the working capital has also a significant role in the ongoing operations of firms operating in different activities. Working capital is a circulating capital and the business's life will not exist when its circulation has stopped [2].

The level of current assets and current liabilities may have a different impact on the performance or the profitability of a given firm. Too much level of current assets may harm the performance of the firm; however, a lower level of current assets may forward to a decreased level of liquidity and stock-outs which poses challenges in maintaining an optimal working capital [3]. Traditionally, the conception of working capital is the offset balance of assets and current liabilities. As a result, working capital management is an effort to administrate, control, and manage the current assets 
and the current liabilities in a given business firm to maximize the profitability or performance and to maintain a proper level of liquidity.

The proper implementation of financial management specifically working capital management is vital for the success of firms. Inefficiency in the financial management of a given firm may harm its performance [4]. When the financial management of a business firm is efficient, it will create a shareholder's value and it is a fundamental element in the overall strategy of the firm [5]. Besides, the performance and liquidity of a firm are affected by the level of working capital management and it is crucial for the firm [6].

Appropriate management of working capital is an essential portion of the whole corporate strategy to add stockholder's worth [5]. Besides, well-organized working capital management helps to advance the operating performance of the firm motives and it helps to attain shortrange liquidity [6]. Hence, firms make an effort to preserve an optimum level of working capital that maximizes their worth [7]. Besides, proper working capital management is very vital for firms since it has a significant impact on the performance and liquidity of firms [8]. The key aim of working capital management is to attain the optimal balance between its components [9].

For instance, one of the components of working capital is inventory; huge inventory and liberal trade credit policy may result from huge sales and huge inventory may also diminish the risk of a stock-out. Trade credit may motivate sales since it permits a business firm to get product quality before disbursing [10]. The other component of working capital is accounts payable; deferring disbursement of accounts payable to vendors lets firms get the quality of procuring products and can be cheap and dynamic means of financing [10]. Instead, differing of such payables can be costly if a firm is provided a discount for prompt payment. Another component of working capital management is accounts receivable; uncollected accounts receivables can result in cash inflow difficulties for the firm [11].

Also, the other major component of working capital is cash; the well-known measure of working capital management is the cash conversion cycle, that is, the period between the disbursement for the procurements of raw materials and the collection of sales of finished products. The prolonged the time spans, the greater the investment in working capital, and also a prolonged cash conversion cycle may escalate profitability since it leads to huge sales [7]. Nevertheless, corporate profitability may diminish with the cash conversion cycle, if the expenses of huge investment in working capital grow quicker than the benefits of holding additional inventory stocks or yielding more trade credit to customers [12]. Besides, the major source of the failure of a business enterprise has been the shortage of working capital, their improper holding, mismanagement of working capital, and underemployment of capacity [3]. Overall, not only is working capital management helping the performance of firms in the current cash-strapped and uncertain economy, but it is the query of attaining the firm's day-to-day operation. Consequently, it is vital to identify and recognize the issue of working capital management and its impact on firms' performance.
Certain investigations have been made in identifying the impact of working capital management on the performance of some firms (local manufacturing firms and banks); however, there was no empirical study done on the impact of working capital management on the performance of exporting firms in Ethiopia. Thus, the absence of investigations made on the impact of working capital management on the exporting firms' performance leads this investigation to be undertaken. As a result, the ultimate purpose of the study was to examine and investigate the impact of working capital management on the performance of exporting firms operating in Ethiopia. To reach this objective, the following hypothesizes was developed and tested: account receivables period, cash conversion cycle, inventory conversion period, and accounts payable period have a significant and positive impact on exporting firms' performance. The account receivables period measured the receivables management of the firm, the cash conversion cycle measured the cash management of the firm, the inventory conversion period measured the inventory management of the firm, and the accounts payable period measured the payables management of the firm.

\section{Statement of the Problem}

In today's business environment, firms needed an adequate resource to assure the going concern of their business activities, and the resources are optimally employed to improve the overall performance [13]. The impact of working capital management on the performance of firms has been investigated by many investigators.

According to the empirical works of literature of this study, the relationship that exists between working capital management and the firms' performance was significant. Though according to [14], some methods employed by the managers in practice to make working capital decisions did not depend on the principles of finance, rather they used their experiences which are weakly made models. This may result in firms to overcapitalization or undercapitalization and then this makes managers ineffectively manage the various combination of working capital features [15].

The investigation made by Boisjoly et al. [11] found that incompetency or incapability of financial managers to design and manage the working capital of the firm may lead to their failure. Firms can have abundant resources and profitability, but they may face illiquidity as their assets are not ready to transform into cash [16]. Thus, we cannot surely say that profitable firms have effective management of working capital. Also, the reason behind having extensive debtors' collection period and narrowed creditors' payment period is that managers disregard their firms' operating cycle [17].

Considering the result of having ineffective management of working capital, the area needs huge investigations and it attracts the attention of different investigators in Ethiopia. However, there are no or few studies that were made on the issue and the problem is almost less investigated and there is a research gap on this part. The managers of different firms operating in Ethiopia are managing the working capital of their firm traditionally which is practically considered as 
narrowing the cash conversion cycle for the increment of the firm's profitability or performance.

The awareness of Ethiopian firm managers regarding the working capital management of their firm to maximize the profitability or the performance is limited and this is because there are no sufficient and appropriate researches done in Ethiopia regarding the issue. Thus, to fill the research gap in this particular study, the impact of working capital management on the performance of exporting firms in Ethiopia was investigated.

\section{Research Objectives}

The main objective of this empirical study is to examine the impact of working capital management on the performance of exporting firms in Ethiopia. Considering the main objective, the following are the specific objectives for this investigation:

(i) To examine the impact of account receivables period on exporting firms' performance

(ii) To examine the impact of the cash conversion cycle on exporting firms' performance

(iii) To examine the impact of inventory conversion period on exporting firms' performance

(iv) To examine the impact of accounts payable period on exporting firms' performance

\section{Literature Review}

Working capital management is an essential part of financial management in all business operations. It is mainly concerned with the management of the liquidity components of companies' short-term current assets and current obligations [18-21]. The most familiar current assets are cash, account receivables, inventory stock and current liabilities consisting of account payables, accrued expenses, and tax liabilities, short-term debt such as commercial bills, and provisions for current liabilities such as dividends declared but not yet paid [21-24].

The main purpose of working capital management is to reduce the volume of capital hold in the current asset portion of a firm which is implied to the cash conversion cycle [25]. Handling and monitoring receivables and their collection issues and managing the investment in the inventory stock are the typical emphasis parts of working capital management. Diverse business presences, sustainability, and performance may be influenced by the proper handling and control of working capital in a particular firm [21].

The working capital policy can be better explained as an approach that offers the parameter to handle the current assets and current liabilities in such a way that it diminishes the risk of failure to pay [4]. The working capital policy is primarily concentrating on the liquidity of current assets to encounter current liabilities. Liquidity is more significant, since if the level of liquidity is excessively high, then a firm has a lot of idle capital, and it has to accept the cost of these idle capitals [25]. Conversely, if liquidity is excessively low, then it will face a deficiency of resources to encounter its current financial obligations [26]. Current assets are a basic factor of working capital and working capital management is also determined by the level of current assets as compared to the level of current liabilities [4]. In this regard, the theoretical aspects of finance categorize working capital policy into three types as defensive or hedging, aggressive, and conservative working capital policy [1].

4.1. Defensive Policy. Firms employ defensive policy by utilizing long-term debt and equity to finance their fixed assets and main parts of current assets. In this policy, the firm concern can implement a financial plan which best fits the estimated life of assets with the anticipated life of the sources of funds gained to finance assets [27]. Inventory stocks that are considered to be traded in 30 days could be funded with a 30-day bank credit, a machine estimated to last for 5 years could be funded with a 5-year credit, a 20-year building could be funded with a 20 -year mortgage bond, and so forth [20].

Defensive policy shrinks the risk by decreasing the current liabilities but it also touches profitability since longterm debt provides a higher interest rate which will escalate the cost of funding [26]. This indicates that a firm is not agreeable to accept the risk and sense it is proper to have cash or near cash balances, higher inventory stocks, and liberal credit terms. Typically, firms that are functioning in an uncertain situation choose to implement such a policy since they are not certain about the impending prices, demand, and short-term interest rate [9]. In such cases, it is good to have a higher level of current assets. This indicates maintaining a higher level of inventory in the stock to attain an unexpected increase in demand and evade the risk of work stoppage in operation and production. This policy provides an elongated cash conversion cycle for the firm [11]. Likewise, it offers protection towards the financial difficulties generated by the shortage of funds to attain the short-term liability but as it was explained earlier, long-term debt has a higher interest rate which will escalate the cost of funding [12]. Correspondingly, resources are tied up in a firm due to the liberal credit policy of the firm and it also has an opportunity cost. Hereafter, this policy may diminish the profitability and the cost of employing this policy may surpass the benefits of the policy [26].

4.2. Aggressive Policy. Firms can employ aggressive policy by financing their current assets with short-term debt since it provides a low-interest rate. Though, the risk related to the short-term debt is more than the long-term debt [15]. In this policy, the whole expected necessity of current assets should be funded from short-term sources, and even a portion of fixed assets financing should be funded from short-term sources [27]. This policy leads the finance mix to being highly risky, less costly, and highly profitable. Moreover, some finance managers accept even high risk by funding a long-term asset with short-term debts and this method drives the working capital on the adverse side [16].

Managers make an effort to boost the profitability by paying a lower interest rate, but this method can bring 
greater risk if the short-term interest rate varies or the cash inflow is not adequate to meet the current liabilities [20]. Consequently, such a policy is implemented by the firm which is functioning in a steady economy and is fairly certain about impending cash flows [13]. A firm with an aggressive working capital policy provides a short credit period to clients, holds smaller inventory stock, and has a lesser level of cash in hand [14]. This policy raises the risk of failure to pay debt since a firm may face a lack of funds to fulfill the short-term liabilities but it also provides a huge return as the high return is connected with taking a high risk [26].

4.3. Conservative Policy. Certain firms want neither to be aggressive by decreasing the level of current assets under current liabilities nor to be defensive by intensifying the level of current assets over the current liabilities [28]. Hence, balancing the risk and return firms are employing the conservative strategy. It is also a combination of defensive working capital policy and aggressive working capital policy. In this method, provisional current assets, assets that exist on the balance sheet for short period will be funded by the short-term obligations and long-term debts have to finance the fixed assets and enduring current assets [20]. Therefore, the implementer of this method discovers a reasonable level of working capital with reasonable risk and return. It is considered a "low-profit low-risk" conception [27]. Besides, this approach not only diminishes the risk of failure to pay the debt but also decreases the opportunity cost of extra investment in the current assets. Conversely, apart from the above arguments, the amount of working capital is also based on the level of sale since sales are the source of revenue for all firms [17]. Sales can affect working capital in three potential ways; as sales grow, the working capital will also rise with the same fraction, so the span of the cash conversion cycle remains the same; as the sales rise, the working capital grows in a slower proportion; as the sales grow, the level of working capital increases in a misappropriate level; that is, the working capital may increase in a proportion more than the proportion of growth in the sale [26].

Firms with a steady sale of rising sale can implement the aggressive approach since it has confidence on its upcoming cash inflows and is certain to disburse its short-term liabilities at maturity [18]. In contrast, a firm with an unbalanced sale or with instability in the sale cannot consider implementing the aggressive approach since it is not certain about its future cash inflows. In such cases, the implementation of an aggressive approach is like committing suicide [22]. Therefore, browsing and utilizing other bests approach may be a wise choice.

Some studies are investigated in different parts of the world regarding the impact of working capital management on the performance of firms. For instance, according to the study made by Lazaridis and Tryfonidis [29], there is a negative association between the performance of the firm which is measured by gross operating profit and the cash conversion cycle. The study implies that to generate higher profit, firms need to narrow the cash conversion cycle. Also, in a study made by Izadi and Taaki [6] on the big and small firms operating in Iran, the performance of firms which is measured by return on asset, and the cash conversion has a significant and inverse relationship. Besides, an investigation which was made by Eljelly [30] also implies that there is a significant and negative correlation between the performance of the firm and the level of liquidity with a long cash conversion cycle. However, the study made by Gitman [21] shows that there is a significant positive correlation between the firms' performance which is measured by return on asset and the management of working capital which is represented by the net liquid balance of firms.

An investigation by Lazaridis and Tryfonidis [29] shows that there is a negative correlation among the performance of the firm which is measured by gross operating profit and the inventory period; however, it is not statistically significant. Furthermore, the study made by Samiloglu and Demirgunes [31] on the listed manufacturing companies in Istanbul Stock Exchange shows that the inventory period has a significant and negative correlation with profitability which is measured by return on asset. Besides, the empirical result of Deloof [7] shows that there is a statistically significant and negative correlation between the inventory period and the gross operating income of firms. This indicates that companies may experience lower profit due to a decrease in sales since the increasing volume of inventory means a decrement in the sales of the firm. Besides, the study made by Boisjoly [32] implies that an improvement of firms' inventory management can be explained by the growth of inventory turnover over fifteen years. Also, the study of Rahman and Nasr [10] on the performance of the firm which is measured by the return on assets of firms shows that there is a significant and negative correlation with the inventory period.

Based on the study of Lazaridis and Tryfonidis [29], there is a negative correlation among the profitability of firms which is measured by gross operating profit and the receivables collection period. The result of the study implies that by diminishing the credit terms given for customers, firms can incise their profitability. Moreover, the investigation of Deloof [7] shows that there is a significant and negative correlation among profitability which is measured by gross operating income and the average accounts receivable period. Also, the study of Boisjoly (2009) implies that the improvement of account receivables management has been given a considerable focus by different firms since over the 15 years their accounts receivable turnover has been increased. Besides, the findings of Raheman and Nasr [10] show that the accounts receivable which were used as a measure of liquidity and the profitability of firms have a significant and negative correlation. Furthermore, the result of the study made by Nuru [33] shows that there is a negative correlation between profitability and the average collection period.

A study was undertaken by Raheman and Nasr [10] regarding the relationship that exists among working capital management and the profitability of small and medium enterprises in Spain, profitability which is measured by the 
return on assets has a significant and negative relationship with the account payables period. Moreover, the study of Nuru [33] on the manufacturing private limited companies in the Tigray region of Ethiopia shows that there is an inverse correlation between the profitability measure and the accounts payable period; however, the variable has no statistically significant correlation with operating profit margin which was used as one of the measures of profitability. Furthermore, the investigation made by Deloof [7] shows that there is an inverse correlation between the profitability and the average accounts payable period which implies that a firm with weak profit needs an extended payment period and the accounts payable policy can be affected by firms' profitability. However, the study of Lazaridis and Tryfonidis [29] revealed that there is a significant and positive correlation between the accounts payable period and the profitability of firms which is measured by gross operating profit.

In Ethiopia, some empirical studies have been made on the impact of working capital management on the profitability of firms. For instance, according to the study made by Abenet and Venkateswarlu [34] on the effect of working capital management on firms' profitability considering the manufacturing companies operating in eastern Ethiopia, the lower profitability may be associated with and resulted from longer receivable periods and inventory periods. Besides, the study of Sheaba et al. [35] shows that the return on asset of Tigray manufacturing firms has a significant and negative correlation with the conversion cycle. Furthermore, based on the study made by Tirngo [8] regarding the impact of working capital management on profitability of Micro and Small Enterprises by taking Bahir Dar as a study case area, the enterprises profitability has a strong positive correlation with a payable period, though receivables period, inventory period, and cash conversion cycle have a negative and significant correlation with profitability. However, as there were some investigations which have been made in identifying the impact of working capital management on the performance of firms in different sectors like local manufacturing and banking firms, there was no empirical study done on the impact of working capital management on the performance of exporting firms in Ethiopia. Thus, the absence of investigations made on the impact of working capital management on the exporting firms' performance leads this investigation to be undertaken. As a result, the ultimate purpose of the study was to examine and investigate the impact of working capital management on the performance of exporting firms operating in Ethiopia. Considering the findings of this study, working capital management which was measured by account receivables period, cash conversion cycle, and accounts payable period has a statistically significant and positive impact on the performance of exporting firms in Ethiopia which was measured by both return on assets and return on investment. However, working capital management which was measured by the inventory conversion period has a statistically significant and positive impact on return on investment, but it has an insignificant impact on the performance of sampled export firms in Ethiopia which was measured by return on assets.

\section{Research Methodology}

In this particular study, the researcher made an investigation on the impacts of working capital management on the performance of exporting firms in Ethiopia. Considering the aim of the study, it was critical to select the best research methods to be employed in undertaking the investigation. For this study, a quantitative method has been utilized since the quantitative method was necessary to make and analyze different correlations and for statistical techniques used by the study. To reach the ultimate objective of the study, mainly explanatory/casual type of research was engaged and in some parts of the study descriptive research type was used.In this particular study, those exporting firms which are currently operating in Ethiopia were considered as the population, and those firms are involved in different exporting activities such as exporting coffee; pulses, oilseeds, and spices; vegetables and fruits; flowers; Tanners, footwear and leather; natural forest and forest products; cotton; meat; live animals; textile and garments; tea; and other agricultural-related products. For the sake of sampling, a list of all major exporting firms registers by the Ministry of Trade [36] was considered and the total number of exporting firms was 277 which are involved in exporting different outputs. To drive a sample from the population, a formula which is provided by Yemane [37] was used since the population was homogeneous, that is, exporting firms, and this research was conducted on 164 sampled exporting firms that are operating in Ethiopia during the investigation. In determining the sample size, the following formula was used by considering the significance level $(\alpha)$ at $5 \%$; hence the confidence level was $95 \%$, where $n=$ sample size:

$$
\begin{aligned}
n & =\frac{N}{1+N(e)^{2}}, \\
N & =\text { Population size }, \\
Z & =\text { confidence level, } \\
e & =\text { the level of precision } \\
& =\frac{277}{1+277(0.05)^{2}}=163.66 \approx 164 .
\end{aligned}
$$

According to Adam [38], it is possible to approximate the sample size of 163.66 to 164 . After determining the sample size, it was critical to determine which sample selection techniques have to be employed. For this study, a stratified sample selection technique was used in the selection of exporting firms and strata of exporting firms for each type of business activities were taken (coffee exporters; Ethiopian pulses, oilseeds, and spices processors exporters; vegetables and fruit exporters; flower exporters; tanners, footwear, and leather products exporters; natural forest and forest products exporters; cotton exporters; exporters of meat; live animal exporters; textile and garment exporters; other agricultural-related exporters; and tea exporters) and randomly sampling units were selected from each stratum. Finally, to investigate the impact of working capital 
management on the performance of Ethiopian exporting firms, the following two multiple linear regression models were formulated.

Model 1:

$$
\mathrm{RTOA}=\beta_{0}+\beta_{1} \mathrm{ARVP}+\beta_{2} \mathrm{CHCC}+\beta_{3} \mathrm{IVCP}+\beta_{4} \mathrm{APYP}+\varepsilon
$$

Model 2:

$$
\mathrm{RTOI}=\beta_{0}+\beta_{1} \mathrm{ARVP}+\beta_{2} \mathrm{CHCC}+\beta_{3} \mathrm{IVCP}+\beta_{4} \mathrm{APYP}+\varepsilon,
$$

where ROTA stands for return on asset and RTOI stands for return on investment, which are the two dependent variables of the study (RTOI = net income/total assets and RTOA $=$ (earnings available for common stockholders/total asset) $* 100)$. Besides, the independent variables for the two models are account receivables period (ARVP) which measures the firms' receivable management (ARVP $=$ average accounts receivables/net sales) *365), cash conversion cycle (CHCS) which measures the firms' cash management (CHCS $=$ average account receivables + average inventories - Average Account Payable), inventory conversion period (IVCP) which measures firms' inventory management $($ IVCP $=($ average inventory/net sales $) * 365)$, and accounts payable period (APYP) which measures the firms' payables management (average accounts payables/net sales) *365), and $\varepsilon$ represents the random error of the model.

\section{Result and Discussion}

After collecting all data from the sample of the study and by considering the two formulated models, the following analysis was made, and in this part, the descriptive statistics and the regression analysis (based on the formulated models) made for the study are presented. In this study, 164 exporting firms operating in Ethiopia are included as a sample, and they were investigated to determine the impact of working capital management on exporting firms' performance. While making the regressions for the study, many tests have been conducted to test the OLS assumptions, and all tests, descriptive statistics, and study results are presented in this section.

As shown in Table 1 for the two models, the average return on asset and return on investment of exporting firms in Ethiopia are 0.14 and 0.18 , respectively. Also, the minimum value of return on asset is -0.19 and its maximum value is 0.47 , and the minimum value of return on investment is -0.15 and its maximum value is 0.65 . This implies that exporting companies have to get satisfactory returns from their operations.

To test the normality of the data the Shapiro-Wilk $W$ test was used and based on the test result shown in Table 2, the $p$ values for the first model (RTOA) are $p \leq 0.4$ and for the second model (RTOI) are $p \leq 0.08$, which are greater than 0.05 and the graph of Kernel density is bell-shaped for the two models; this implies that the data is normal. Besides, to test the reliability of variables in the study Cronbach's alpha test of reliability was used and the scale reliability coefficients in Table 2 for the first model (RTOA) is 0.9628 and for the second model (RTOI) is 0.9628 , which are greater than 0.7 ; this indicates that all variables used in the study are reliable.

The tests depicted in Table 3 are used to test multicollinearity, autocorrelation, and heteroscedasticity problems. Accordingly, the results show that the mean value of VIF for the two models (RTOA and RTOI) is 7.52, the d-statistics of the Durbin-Watson test for the first model is 1.42 and for the second model is 1.34 which are close to 2, and the $p$ value of Breusch-Pagan/Cook-Weisberg for the first model (RTOA) is $p \leq 0.7$ and for the second model (RTOI) is $p \leq 0.08$. Thus, the results imply that there is no collinearity, no autocorrelation, and no heteroscedasticity problem. The benchmarks for those tests were derived from Gujarat [39].

Based on the regression results displayed in Tables 4 and 5 , account receivables period (ARVP), cash conversion cycle (CHCS), inventory conversion period (IVCP), and accounts payable period (APYP) are explained about $98.99 \%$ $\left(R^{2}=0.9899\right)$ and $98.62\left(R^{2}=0.0 .9862\right)$ of export firms' performance in Ethiopian which is measured by return on asset and return on investment, respectively.

The regression outputs in Table 4 and Table 5 imply that the payables management which was measured by the account receivables period (ARVP) has a highly significant and positive relationship with the performance of exporting firms (Coef. $=0.0019619$ and 0.0026233 , and $p \leq 0.001$ ). The result implies that the changes made on exporting firms' account receivables period have a direct impact on their performance. This result is contradicted with the study made by Chen and Kieschnick [14], Lazaridis and Tryfonidis [29], Deloof [7], Raheman and Nasr [10], Enqvist et al. [25], and Nuru [33] who concluded that there is a negative correlation between the performance of firms and the receivables collection period. The result implies that giving higher credit terms to customers of exporting firms may increase their performance.

Moreover, as is shown in the regression output of $\mathrm{Ta}$ bles 4 and 5, the cash management which was measured by the cash conversion cycle (CHCC) has a highly significant and positive relationship with the performance of exporting firm's (Coef. $=0.0020022$ and 0.0017141, and $p \leq 0.001$ ). However, this result was contradicted with the study made by Peng and Zhou [13], Lazaridis and Tryfonidis [29], Izadi and Taaki [6], and Eljelly [30] who concluded that there is a negative relationship between the performance of firms and the cash conversion cycle. On the other hand, the study results made by Gitman [21], Ukaegbu [16], and Delsing et al. [9] are the same as this study result showing there is a

TABLE 1: Descriptive statistics summary.

\begin{tabular}{lccccc}
\hline Variable & Obs. & Mean & Std. dev. & min. & max. \\
\hline RTOA & 164 & 0.1405488 & 0.1733653 & -0.19 & 0.47 \\
RTOI & 164 & 0.1848171 & 0.2190959 & -0.15 & 0.65 \\
ARVP & 164 & 31.80866 & 30.5363 & 0.09 & 95.75 \\
CHCC & 164 & 37.95427 & 41.69354 & -81.5 & 95.75 \\
IVCP & 164 & 50.18159 & 65.8716 & 0 & 235 \\
APYP & 164 & 193.997 & 131.7826 & 77 & 491.5 \\
\hline
\end{tabular}


TABLE 2: Shapiro-Wilk $W$ test for normal data and Cronbach's alpha test of reliability.

\begin{tabular}{|c|c|c|c|c|c|c|c|c|c|c|c|}
\hline \multicolumn{6}{|c|}{ RTOA } & \multicolumn{6}{|c|}{ RTOI } \\
\hline \multicolumn{6}{|c|}{ Shapiro-Wilk $W$ test } & \multicolumn{6}{|c|}{ Shapiro-Wilk $W$ test } \\
\hline Variable & Obs. & $W$ & $V$ & $z$ & Prob $>z$ & Variable & Obs. & $W$ & $V$ & $z$ & Prob $>z$ \\
\hline$R$ & 164 & 0.99120 & 1.106 & 0.229 & 0.40949 & $r$ & 164 & 0.98559 & 1.811 & 1.352 & 0.08816 \\
\hline \multicolumn{6}{|c|}{ Cronbach's alpha test of reliability } & \multicolumn{6}{|c|}{ Cronbach's alpha test of reliability } \\
\hline \multicolumn{4}{|c|}{ Average interitem covariance } & \multicolumn{2}{|c|}{0.8335} & \multicolumn{4}{|c|}{ Average interitem covariance } & \multicolumn{2}{|c|}{0.8382} \\
\hline \multicolumn{4}{|c|}{ Number of items in the scale } & \multicolumn{2}{|c|}{5} & \multicolumn{4}{|c|}{ Number of items in the scale } & \multicolumn{2}{|c|}{5} \\
\hline \multicolumn{4}{|c|}{ Scale reliability coefficient } & \multicolumn{2}{|c|}{0.9616} & \multicolumn{4}{|c|}{ Scale reliability coefficient } & \multicolumn{2}{|c|}{0.9628} \\
\hline
\end{tabular}

TABLE 3: Multicollinearity test, test of autocorrelation, and test of heteroscedasticity.

\begin{tabular}{|c|c|c|c|c|c|}
\hline \multicolumn{3}{|c|}{ RTOA } & \multicolumn{3}{|c|}{ RTOI } \\
\hline \multicolumn{3}{|c|}{ Multicollinearity test } & \multicolumn{3}{|c|}{ Multicollinearity test } \\
\hline Variable & VIF & $1 / \mathrm{VIF}$ & Variable & VIF & 1/VIF \\
\hline IVCP & 1.29 & 0.088550 & IVCP & 1.29 & 0.088550 \\
\hline ARVP & 9.63 & 0.103791 & ARVP & 9.63 & 0.103791 \\
\hline APYP & 5.87 & 0.170326 & APYP & 5.87 & 0.170326 \\
\hline CHCC & 3.26 & 0.306489 & CHCC & 3.26 & 0.306489 \\
\hline \multicolumn{3}{|l|}{ Mean VIF } & Mean VIF & \multicolumn{2}{|c|}{7.52} \\
\hline Durbi & $\begin{array}{l}\text {-Watso } \\
\text { tatistic } \\
\text { /Cook- } \\
2(1)=0 \\
\text { chi2 }=0\end{array}$ & 306 & Durb & $\begin{array}{l}\text {-Wats } \\
\text { atistic } \\
\text { Cook- } \\
(1)=2 \\
\text { chi2 }=\end{array}$ & 941 \\
\hline
\end{tabular}

TABLE 4: Regression result model one (RTOA).

\begin{tabular}{|c|c|c|c|c|c|c|}
\hline Source & SS & df & MS & & \multicolumn{2}{|c|}{ Number of obs $=164$} \\
\hline Model & 4.85090369 & 4 & 1.21272592 & & \multicolumn{2}{|c|}{$F(6,265)=4004.90$} \\
\hline Residual & 0.048146921 & 159 & 0.000302811 & & \multicolumn{2}{|c|}{ Prob $>F=0.0000$} \\
\hline Total & 4.89905061 & 163 & 0.030055525 & & \multirow{2}{*}{\multicolumn{2}{|c|}{$\begin{array}{c}R \text {-squared }=0.9902 \\
\text { Adj } R \text {-squared }=0.9899 \\
\text { Root MSE }=0.0174\end{array}$}} \\
\hline & & & & & & \\
\hline RTOA & Coef. & Std. err. & $T$ & $p 0>t$ & \multicolumn{2}{|c|}{ (95\% conf. interval) } \\
\hline ARVP & 0.0019619 & 0.0001385 & 14.16 & $\leq 0.001$ & 0.0016883 & 0.0022355 \\
\hline $\mathrm{CHCC}$ & 0.0020022 & 0.000059 & 33.91 & $\leq 0.001$ & 0.0018855 & 0.0021188 \\
\hline IVCP & 0.0001359 & 0.0000695 & 1.95 & $\leq 0.052$ & $-1.48 e-06$ & 0.0002732 \\
\hline APYP & 0.0002701 & 0.0000251 & 10.78 & $\leq 0.001$ & 0.0002206 & 0.0003196 \\
\hline _cons & -0.0570715 & 0.0033467 & -17.05 & $\leq 0.001$ & -0.0636812 & -0.0504618 \\
\hline
\end{tabular}

TABLE 5: Regression result model two (RTOI).

\begin{tabular}{|c|c|c|c|c|c|c|}
\hline Source & SS & $\mathrm{df}$ & MS & & \multicolumn{2}{|c|}{ Number of obs $=164$} \\
\hline Model & 7.71919863 & 4 & 1.92979966 & & \multicolumn{2}{|c|}{$F(6,265)=2914.06$} \\
\hline Residual & 0.105295884 & 159 & 0.000662238 & & \multicolumn{2}{|c|}{ Prob $>F=0.0000$} \\
\hline Total & 7.82449451 & 163 & 0.048003034 & & \multicolumn{2}{|c|}{$R$-squared $=0.9865$} \\
\hline & & & & & \multirow{2}{*}{\multicolumn{2}{|c|}{$\begin{array}{c}\text { Adj } R \text {-squared }=0.9862 \\
\text { Root MSE }=.02573\end{array}$}} \\
\hline & & & & & & \\
\hline RTOI & Coef. & Std. err. & $T$ & $p>t$ & \multicolumn{2}{|c|}{ ( $95 \%$ conf. interval) } \\
\hline ARVP & 0.0026233 & 0.0002049 & 12.80 & $\leq 0.001$ & 0.0022187 & 0.003028 \\
\hline $\mathrm{CHCC}$ & 0.0017141 & 0.0000873 & 19.63 & $\leq 0.001$ & 0.0015416 & 0.0018866 \\
\hline IVCP & 0.0006118 & 0.0001028 & 5.95 & $\leq 0.001$ & 0.0004087 & 0.0008149 \\
\hline APYP & 0.0003393 & 0.0000371 & 9.16 & $\leq 0.001$ & 0.0002661 & 0.0004125 \\
\hline _cons & -0.0602131 & 0.0049492 & -12.17 & $\leq 0.001$ & -0.0699878 & -0.0504384 \\
\hline
\end{tabular}


positive relationship between the cash conversion cycle and the performance of firms. The result implies that firms may need to prolong their cash conversion cycle to increase their performance.

Besides, the regression output in Table 5 shows that the inventory management which was measured by inventory conversion period (IVCP) has a highly significant and positive relationship with the performance of exporting firm's which was measured by return on investment (Coef. $=0.0006118$ and $p \leq 0.000$ ).

However, the regression output shown in Table 4 implies that the inventory conversion cycle has an insignificant impact on the performance of exporting firms which was measured by return on asset (Coef. $=0.0001359$ and $p \leq 0.052$ ). This result is similar to Aktas et al. [18], Boisjoly et al. [11], and Lazaridis and Tryfonidis [29] since they found that there is insignificant relation between inventory period and firms performance; however, the sign of the relationship is not the same. On the contrary, the study made by Dhole et al. [15], Samiloglu and Demirgunes [31], Deloof [7], Apaka et al. [28], and Raheman and Nasr [10] clearly shows that there is a statistically significant and negative correlation between the performance of firms and the inventory conversion period. The result implies that companies may experience higher performance since the increasing volume of inventory may not mean a decrement in the sales of the firm.

Likewise, the result of the regression output in Tables 4 and 5 shows that the payables management which was measured by accounts payable period (APYP) has a significant and positive impact on the performance of exporting firms (Coef. $=0.0002701$ and 0.0003393, and $p \leq 0.052)$. However, this result is contradicted with the study made by Chauhan [12], Raheman and Nasr [10], Nuru [33], Kasirana et al. [17], and Deloof [7] which concluded that the payable period harms a firm's performance. On the other hand, the result of this study was the same as the study of Mun and Jang [22], Lazaridis and Tryfonidis [29], and Banos-Caballero et al. [1] which revealed that there is a significant and positive correlation between the accounts payable period and the profitability of firms. The result implies that a firm with strong performance may need an extended payment period and the accounts payable policy can affect the firms' performance.

Finally, by considering the multiple regression analysis results of the study which are shown in Tables 4 and 5, account receivables period (ARVP), cash conversion cycle (CHCS), and accounts payable period (APYP) have a statistically significant and positive correlation with the performance of exporting firms in Ethiopia which is measured by both returns on asset and return on investment. However, the inventory conversion period has a statistically significant and positive correlation with the performance of exporting firms in Ethiopia, which was measured by return on investment, but it has a statistically insignificant correlation with the performance of exporting firms in Ethiopia which was measured by return on asset.

Overall, as it is shown in the above analysis, the performance of Ethiopian exporting firms was positively and significantly influenced by the major components of working capital management (which was measured by return on asset and return on investment) such as cash conversion cycle, account receivables period, and account payables period mainly. Exporting firms' performance which was measured by return on investment was also significantly and positively influenced by the inventory conversion period. Hence, exporting firms in Ethiopia shall consider the result of this study while making decisions regarding their working capital management to support their performance. For instance, firms may need to extend credit terms for customers, may prolong their cash conversion cycle, and may need an extended payment period.

\section{Conclusion and Recommendation}

The ultimate objective of this empirical study was to examine the impact of working capital management on the performance of exporting firms in Ethiopia. Using the quantitative approach, the cross-sectional data was analyzed through the multiple regression models. To undertake this study, 164 exporting firms operating in Ethiopia were included as the study sample. Based on the results of the regression analysis account receivables period, cash conversion cycle, inventory conversion period, and accounts payable period have a statistically significant and positive correlation with the performance of exporting firms in Ethiopia. However, the inventory conversion period has an insignificant correlation with the performance of exporting firms which was measured by return on an asset in Ethiopia. By noticing the outcomes of the study, we can conclude that exporting firm's managers in Ethiopia need to refer to the influencing factors which positively and significantly correlate with their performance. In conclusion, the following recommendations are posted given the results of the study.

(i) As the working capital management which was measured by the account receivables period, cash conversion cycle, and accounts payable period have a statistically significant and positive correlation with the performance of exporting firms in Ethiopia which was measured by return on asset and return on investment, exporting firms may need to extend credit terms for their customers, may prolong their cash conversion cycle, and may need an extended payment period to the extent of the number of their debts. However, all the extended periods and cycles have to be made up to the optimum level of working capital management. Also, the inventory conversion period has a statistically significant and positive correlation with the performance of exporting firms in Ethiopia, which was measured by return on investment, but it has an insignificant correlation with return on asset. As a result, firms may or may not hold a high volume of inventory. Thus, it is advisable to consider the result of this study while making decisions regarding their working capital management to support their performance; specifically they have to maintain an optimal level of working capital in their operations. For instance, to attain a high 
volume of sales, they may need to provide extended credit terms for their customers, to use their debit fiancé optimally, and to secure their payment potential they may need to extend their payment periods by dealing with their creditors. Indeed, according to this study result, exporting firms is better to implement a conservative policy of working capital management.

(ii) The outcome of this investigation is almost contradicted with the investigations which were made by other researchers related to the study area. Thus, it is better to make further investigations by future researchers in this regard. Also, future researchers are recommended to give attention to the statistically insignificant variable in this study.

(iii) Besides, it is better to make further studies on the factors which are contributed to the high performance of exporting firms since there are diversities in the method, subject area, and understandability of works of literature from country to country.

\section{Data Availability}

The data of this study were collected from the sample of the study and it is available online.

\section{Conflicts of Interest}

The author declares that there are no conflicts of interest.

\section{References}

[1] S. Banos-Caballero, P. J. García-Teruel, and P. MartínezSolano, "Net operating working capital and firm value: a cross-country analysis," BRQ Business Research Quarterly, pp. 1-17, 2019.

[2] J. D. Aggarwal, "A goal pProgramming model for working capital management," Finance Journal India, vol. 2, no. 1, pp. 16-25, 2000.

[3] J. C. Van Horne and J. M. Wachowicz, Fundamentals of Financial Management, Prentice-Hall, New York, NY, USA, 14th edition, 2004.

[4] D. R. Emery, J. D. Finnerty, and J. D. Stowe, Corporate Financial Management, Pearson Education Inc., Hoboken, NJ, USA, 2nd edition, 2004.

[5] M. Nazir and T. Afza, "Impact of working capital aggressiveness on companies' pProfitability," The IUP Journal of Applied Science, vol. 15, no. 8, pp. 19-30, 2009.

[6] N. Izadi and A. Taaki, "Examining the impact of working capital management on the pProfitability of the Tehran listed firms," Financial Accounting Journal, vol. 2, no. 5, pp. 120-139, 2010.

[7] M. Deloof, "Does working capital management affect pProfitability of Belgian firms?" Journal of Business Finance Accounting, vol. 30, no. 3-4, pp. 573-588, 2003.

[8] D. Tirngo, "Impact of working capital management on pProfitability of micro and small enterprises in Ethiopia: the case of Bahir Dar City Administration," International Journal of Accounting and Taxation, vol. 1, no. 1, pp. 15-24, 2013.

[9] G. A. Delsing, M. R. H. Mandjes, . J. C. Spreij, and E. M. M. Winands, "pppppAn otimization aroach to adative multi-dimensional caital management," Insurance: Mathematics and Economics, vol. 84, pp. 87-97, 2019.

[10] A. Raheman and M. Nasr, "Working capital management and pProfitability-case of Pakistani firms," International Review of Business Research Papers, vol. 3, no. 1, pp. 279-300, 2007.

[11] R. P. Boisjoly, T. E. Conine, and M. B. McDonald, "Working capital management: financial and valuation impacts," Journal of Business Research, vol. 108, pp. 1-8, 2020.

[12] G. S. Chauhan, "pAre working caital decisions truly short-term in nature?" Journal of Business Research, vol. 99, pp. 238-253, 2019.

[13] J. Peng and Z. Zhou, "pppppPpWorking caital otimization in a suly chain ersective," European Journal of Operational Research, vol. 277, no. 3, pp. 846-856, 2019.

[14] C. Chen and R. Kieschnick, "Bank Credit and corporate working capital management," Journal of Corporate Finance, vol. 48, pp. 579-596, 2018.

[15] S. Dhole, S. Mishara, and A. M. Pal, "Efficient working capital management, financial constraints and firm value: a tax-based analysis," Pacific-Basin Finance Journal, vol. 58, pp. 101-212, 2019.

[16] B. Ukaegbu, "The significance of working capital management in determining firm pProfitability: evidence from developing economies in africa," Research in International Business and Finance, vol. 31, pp. 1-16, 2014.

[17] F. W. Kasiran, N. A. Mohamad, and O. Chin, "Working capital management efficiency: a study on the small medium enterprise in Malaysia," Procedia Economics and Finance, vol. 35, pp. 297-303, 2016.

[18] N. Aktas, E. Croci, and D. Petmezas, "pPIs working caital management value-enhancing? Evidence from firm erformance and investments," Journal of Corporate Finance, vol. 30, pp. 98-113, 2015.

[19] J. Sanger, Essential of Working Capital Management, John Wiley \& Sons, Hoboken, NJ, USA, 1st edition, 2011.

[20] E. Brigham and M. Ehrhardt, Financial Management: Theory and Practice, South-Western Cengage Learning, Boston, MA, USA, 13rd edition, 2011.

[21] L. J. Gitman, Principles of Managerial Finance, Pearson Prentice Hall, Boston, MA, USA, 12th edition, 2009.

[22] S. G. Mun and S. Jang, "Working capital, cash holding, and pProfitability of restaurant firms," International Journal of Hospitality Management, vol. 48, pp. 1-11, 2015.

[23] B. Egbide, "Working capital management and pProfitability of listed companies in Nigeria," Nigeria Research Journal of Accountancy, vol. 1, no. 1, pp. 44-53, 2009.

[24] P. Chandra, Financial Management Theory and Practice, McGraw Hill Publishing Company Ltd, New Delhi, India, 1st edition, 1984.

[25] J. Enqvist, M. Graham, and J. Nikkinen, "The impact of working capital management on firm pProfitability in different business cycles: evidence from Finland," Research in International Business and Finance, vol. 32, pp. 36-49, 2014.

[26] G. Arnold, Corporate Financial Management, Pearson Education Limited, New York, NY, USA, 4th edition, 2008.

[27] C. Paramasivan and T. Subramanian, Financial Management, New Age International (P) Ltd., New Delhi, USA, 2009.

[28] S. pAak, A. F. Açıkgöz, E. R. Erbay, and G. Tuncer, "Cash vs. Net working capital as strategic tools for the long-term relation between bank credits and liquidity: inequalities in Turkey," Procedia - Social and Behavioral Sciences, vol. 235, pp. 648-655, 2016.

[29] J. Lazaridis and D. Tryfonidis, "Relationship between working capital management and pProfitability of listed companies in 
the athens stock Exchange," Journal of Financial Management and Analysis, vol. 19, no. 1, pp. 26-35, 2006.

[30] A. M. Eljelly, "Liquidity-pProfitability tradeoff: an empirical investigation in an emerging market," International Journal of Commerce \& Management, vol. 14, no. 1, pp. 48-61, 2004.

[31] F. Samiloglu and K. Demirgunes, "ppPThe Effect of Working Caital Management on Firm rofitability: Evidence from Turkey," ppThe International Journal of Alied Economics and Finance, vol. 2, no. 1, pp. 44-50, 2008.

[32] R. P. Boisjoly, "The cash flow implications of managing working capital and capital investment," Journal of Business and Economic Studies, vol. 15, no. 1, pp. 98-108, 2009.

[33] M. Nuru, "The Effect of Working Capital Policies Management on Firms' Profitability," Unpublished thesis, Addis Ababa University, Addis Ababa, Ethiopia, 2011.

[34] Y. H. Abenet and P. Venkateswarlu, "Effect of working capital management on firms pProfitability evidence from manufacturing companies in eastern, Ethiopia," International Journal of Applied Research, vol. 2, no. 1, pp. 643-647, 2016.

[35] R. Sheaba and A. A. Haftu, "The impact of working capital management on Firm's pPerformance (A case study on endowment fund for rehabilitation of Tigray (E.F.F.O.R.T) manufacturing companies)," International Journal of Commerce and Management Research, vol. 3, no. 9, pp. 29-39, 2017.

[36] Ministry of Trade, "List of all major exporting firms in Ethiopia," https://agoa.info/images/documents/4047/ethiopia -exporters.pdf.

[37] T. Yemane, Applied Sampling, Academic Press, New York, NY, USA, 1967.

[38] A. M. Adam, "Sample size determination in survey research," Journal of Scientific Research and Reports, vol. 26, no. 5, pp. 90-97, 2020.

[39] A. Gujarat, Basic Econometrics, The McGraw-Hill Companies, New York, NY, USA, 4th edition, 2004. 